\title{
Human Capital, Entrepreneurial Capital and SME's Performance of traditional herbal industries in Central Java, Indonesia: The Mediating Effect of Competitive Advantage
}

\author{
Ngatno \\ Doctoral Program of Social Science, Diponegoro University \\ Jl. Prof. Sudarto, SH., No. 1 Tembalang, Semarang \\ Central Java, INDONESIA \\ Apriatni, E.P. \\ Department of Business Administration \\ Faculty of Social and Political Science \\ Diponegoro University, Semarang Central Java, Indonesia \\ Widayanto. \\ Department of Business Administration \\ Faculty of Social and Political Science \\ Diponegoro University, Semarang Central Java, Indonesia
}

\begin{abstract}
This study provides new insights by examining effects of human capital and entrepreneurial capital on competitive advantage and performance. The samples of this study were owners of SME's traditional herbal industries in Central Java, Indonesia. Thirty-five questionnaires were distributed, and they made $32(91.43 \%)$ response rate. The data was analyzed using Generalized Structured Component Analysis (GSCA). The results reveal that: a) human capital and entrepreneurial capital have a positive effect on competitive advantage; b) human capital and entrepreneurial capital do not directly affect SMEs' performance; c). Competitive Advantage fully mediates between human capital and entrepreneurial capital on SMEs' performance. The findings offer an insight for the SMEs in traditional herbal industries: to increase their performance the human and entrepreneurial capital need to be developed. Limitations of this study, first, only small tradtional herbal industries were investigated. The small industries which are more specific in nature, such as the batik, toys, and craft SMEs, may result in different relations between the constructs of the models; second, the data was collected in a single central area of traditional herbal industry. There was no evidence of sampling bias, but future studies would benefit from inclusion of a wider geography scope; third the findings of this study also underscore the need for researchers to examine other factors which may also be antecedents of the SMEs' performance and competitive advantage.
\end{abstract}

Keyword: Human Capital, Entrepreneurial Capital, Competitive Advantage, Performance. 


\section{INTRODUCTION}

In recent years entrepreneurship policies that aim at encouraging entrepreneurial activities have been implemented in many industrial economies. Small and Medium Enterprises (SMEs) have played an important role in developed and developing economies. SMEs are the engines of global economic growth. Kušar, Duhovnik, Grum, \& Starbek, 2004, argue that if SMEs can fulfill customers' demands according to the features and quality of the products, they can successfully enter the universal market.

The role of SMEs in Indonesia's economy is very significant. According to Indonesian Central Bureau of Statistics (2013), there were 57.9 million SMEs in Indonesia and they accounted for 99.9\% of total enterprises. The SMEs in Indonesia employ 114.144 .082 people, the figure of which is equal to $97.3 \%$ of the total Indonesian workforce. Moreover, the SMEs' contribution to gross domestic product (GDP), excluding oil and gas, is $57.12 \%$. Herbal industries have displayed encouraging figures. Ten medium-large scale herbal medicine industries were recorded, and one thousand SMEs-scale herbal medicine industries are scattered in various regions in Indonesia, especially in Java. The herbal industries can absorb hundreds of thousands of workers. Herbal medicine sales over the turn of this year are targeted to reach $\$ 150$ billion. This figure increased to $\$ 5.0$ billion compared to last year which reached $\$ 145$ billion. Besides that, the SMEs have proved to be resistant to a wide range of economic crisis shocks. Thus, the SMEs have become significant to strengthen micro, small and medium enterprises which involve many stakeholders.

To survive the era of global technology, Indonesian government need to think about strengthening people's economy. In the era, the people's economy is expected to have a reliable system in order to improve the people's welfare. To achieve an adequate level of people's welfare, economic growth needs to be underpinned by strengthening SMEs and cooperatives. Yet, this effort has not been able to optimally increase productivity, so the SMEs are highly susceptible to the effects of global competition. In addition, there are still inequalities and underdevelopment between the SMEs and large enterprises (LEs). For that reason, the Indonesian government need to work to improve the potential of the SMEs in order to be competitive, so they can keep up with the other economic activities as well as to keep up with SMEs and Les in other countries.

Successful enterprise creation normally requires substantial tangible and/or intangible resources. The tangible resources can be physical or financial capital. However, the challenge for emerging enterprises is to be able to demonstrate the intangible resources embedded in the venture, such as the entrepreneurial capital and human capital, to venture capitalists and other prospective stakeholders. It is inevitable that the quality of the institutions in SMEs is averagely weak in management, so it is necessary to get attention from researchers. In so doing it is necessary to study the competitiveness of traditional herb SMEs in Sukoharjo, Central Java, and what factors which affect the performance of the SMEs.

This paper focuses on the traditional herb SMEs because they represent the hallmark of productivity, and the traditional herb SMEs can contribute significantly to GDP growth. Furthermore, the traditional herb SMEs employ approximately 5-6 million people. This paper aims to suggest a conceptual framework for a potential relation of entrepreneurial capital, human capital, competitive advantage and performance of traditional herb SMEs in Sukoharjo, Central Java, Indonesia. With reference to the underlying theory and empirical research, a conceptual framework is proposed. The last section discusses implications for policy makers, SMEs owner-managers and researchers. 


\section{STATEMENT OF THE PROBLEM}

Research interest in SMEs has been predicated on its recognisable economic contributions and benefits, particularly in generating employment and alleviating poverty. Scholars have postulated that the SMEs are the panacea for the economic problems of the less developed and developing countries. In Indonesia today, a lot of attention is being directed to the SMEs because of the expected contribution they could make in providing training grounds for the development of indigenous entrepreneurs. However, most SMEs die within their first five years of existence, another smaller percentage goes into extinction between the sixth and tenth year. Thus, only about five to ten percent of young SMEs survive, thrive and grow to maturity. The implication of this is that the survival rate of SMEs in Indonesia is less than $10 \%$ in the first five years of existence. This also suggests that the SMEs in Indonesia have not been able to contribute significantly to economic development as much as it is expected. A general observation on efforts to boost the SMEs' growth and performance has shown that such efforts have mostly been targeted at the aspect of financing and providing infrastructure. The situation is against this background which this study set out to examine the effects of entrepreneurial capital, human capital and competitive advatage on SME's traditional herbal industries Performance, in Sukoharjo, Central Java, Indonesia..

\section{Firm Performance}

\section{LITERATURE REVIEW AND HYPOTHESES.}

Firm performance has been actively investigated from both practitioners and academicians in the measurement of recent reports and articles on the topics which appear at a rate of one every five hours on every working day since 1994 (Pont \& Shaw, 2003). The firm performance is a relevant construct in strategic management research, and it is frequently used as a dependent variable. Despite its relevance, there is a scarce consensus about its definition, dimension, and measurement; accordingly, the scarcity limits advances in research and understanding of the construct.

The concept of firm performance is generally centered on either efficiency or effectiveness. Since business enterprises need to eventually be profitable to survive, financial efficiency in several forms (e.g., gross margins, net margins, ROI, relative profitability) is typically used as an ultimate outcome when the performance is included in research. The outcome particularly utilizes self-reports on financial and non-financial measure, and each measure is one of the most commonly used definitions of firm performance in the research. The financial measure is focused on overall profit level, profit margin, and return on investment in finance; whereas the non-financial measure is related to customer and employee satisfaction.

Researchers usually distinguish subjective and objective measures. The objective measures are usually market-based indicators, accounting-based measures, revenues, ROI and profit as well as growth measures; the measures consider employee and sales growth, and survival. The subjective measures can be described as perceptual in nature and they refer to subjective assessments of performance which is dependent upon a manager's expectation. The level of the assessment of performance is in comparison with competitors. In this research, four concepts are employed to tap both efficiency and effectiveness in rural credit bank performance.

\section{Direct Effects of Human Capital on SMEs Performance}

The birth of human capital theory was announced in 1960 by Theodore Schultz (Mark Blaug, 1976). In the past, the human capital means of production which constitutes a major share of an organization's tangible assets. Today, human talent is considered as a capital; talented people carry within them, in their knowledge and expertise, important aspects of the means of 
production. Firms' capacity to compete is imbedded in its founder's capability, education, and experience. The main focus of the human capital theory is on the outcome of investment in education and work experience (Becker, 1993). The human capital encompasses abilities which are influenced in part by genetic factors (e.g., intelligence, health, personality, attractiveness) and those which are acquired as skills, such as education, job training, tenure, work experience, and interpersonal relationships (Shanahan \& Tuma, 1994 cited by Markman, \& Baron 2003). The human capital theory is concerned with decisions with respect to investments in education and work experience (Becker, 1993). Since 1990s, many researchers in the fields of economics, human resource management, social sciences, and entrepreneurship have applied the human capital theory in different perspectives. With respect to entrepreneurship, the theory focuses on the business founder's acquired human capital attributes (Isaksen, 2006). Because of that, several researchers focus their research attention on human capital perspectives as one of the determinants of the business success. This section describes a degree of relation between the human capital and small businesses success.

Previous studies on effects of human capital on SMEs performance have been inconclusive. Empirical findings show that there is a positive relation between human capital and business success. However, there is a contradictory view upon operationalization of human capital; the effect of human capital on the business success, and determination of human capital attributes (Rauch \& Frese. M., 2000). For instance, Lussiers \& Pfeifer (2001) find that human capital of individual entrepreneurs play a role in contributing the success of the entrepreneurs. Their study find that an entrepreneur with industrial experience, motivation and business start up, has a greater chance of succeeding than those with minimal industrial experience and little motivation. The finding of Bosma et al. (2004) is also consistent with the other researchers, stating that human capital development has a positive relation to SMEs' performance. Datta et al., (2005) also affirm that human capital scheme have been found, within a number of different establishments, to positively affect organizational performance. Oforegbunam \& Okorafor, (2010) show that increased human capital development by sampled SMEs leads to significant improvements in the SME's performance. Moreover, on the-job training has been identified as the most significant option for developing the human capital of SMEs for enhanced performance. Fatoki (2011) also shows that there is a significant positive relation between human capital and SMEs performance. Ojokuku, R.M. \& Sajuyigbe, A.S, (2015) find that levels on- the- job training, levels of formal education, levels of participation in trade fairs and exhibitions are related to each other. Based on this rationale, as shown in Figure. 1, the following hypothesis is proposed:

\section{H1: Human Capital is positively and significantly related to SMEs' performance}

\section{Direct effect of Entrepreneurial Capital on SMEs Performance}

The concept of 'entrepreneurial capital' has emerged recently in recognition that business ownership is predicated on the availability of and access to financial and non-financial resources (Morris, 1998; Erikson, 2002; Firkin, 2003). Successful enterprise creation normally requires substantial tangible or intangible resources. The tangible resources can be physical or financial capital. However, the challenge for emerging enterprises is to be able to demonstrate the intangible resources embedded in the venture, such as the entrepreneurial capital and human capital, to venture capitalists and other prospective stakeholders. It is the quality of the entrepreneurial capability, that is, its ability to generate future income services, which actually accounts for its efficiency. Therefore, informal venture capitalists exercise common sense when they do not invest in venturing individuals or emerging ventures if satisfactory competence and commitment are not evident. 
Previous research has typologized capital into three categories, that is, physical (Hofer \& Schendel, 1978), financial (Bygrave, 1989), and human (Becker, 1964). Others have extended the capital reasoning and developed the phenomena to include social capital (Bordieu, 1983; Leibenstein, 1968; Glade, 1967; Johannisson, 1988; Nahapiet \& Ghoshal, 1998) and organizational capital (Dollinger, 1995; Tomer, 1987; Hofer \& Schendel, 1978).

However, none of the above dimensions reflect the important role of the nascent entrepreneur who first developed the possibilities of the new venture (Brush et al., 1997; Shaver \& Scott, 1991). The dimensions are not useful either in indicating the possible outcomes when a competent but visionary, nascent entrepreneur sees a venture through to fruition. The potential stakeholders need to be at a minimum trust in the individual or the team they are investing in, and invest only when they are convinced there is a potential for sustained, competent, future entrepreneurial behavior.

The entrepreneurial capital may also be regarded as an extension of human capital theory, which holds that human capital is a rather homogenous resource. Moreover, Schultz (1970) suggests that quality improvements in inputs are fundamental for the understanding of value creation in societies. According to him, it is the quality of capital, or its ability to generate future income services, that is the cornerstone of wealth creation. Schultz $(1970,300)$ states "If we were unable to observe these (capital) inequalities, we would have to invent them because they are the mainspring of economic growth." Accordingly, entrepreneurial capital is treated as a heterogeneous resource, consisting of a set of complementary human capacities.

The concept of entrepreneurial behavior can be used in the way that the entrepreneurial capital can also be considered as a present value of the resulting entrepreneurial behavior in the future. As Gartner \& Carter (2003) state, "Entrepreneurial behavior involves the activities of individuals who are associated with creating new organizations rather than the activities of individuals who are involved with maintaining or changing the operations of on-going established organizations." This view is also in accordance with another capital terminology, like social capital, which has been conceptualized as the amount of available resources (Glade, 1967; Leibenstein, 1968; Granovetter, 1983; Bourdieu, 1983; Nahapiet \& Ghoshal, 1998). Entrepreneurship is conceptualized as a process by which individuals pursue opportunities without regard to resources which are currently under their control (Stevenson \& Jarillo, 1990). Koch \& McGrath (1996) state that the potential latent of entrepreneurial capital can be conceptualized as the present value of the several options available.

Ulrich (1998) defines intellectual capital as a function of multiplication of competence and commitment. Multiplication function is extended to include entrepreneurial competencies and entrepreneurial commitment, and the extension will make the idea of entrepreneurial capital. Entrepreneurial competence may then be understood as a combined capacity to identify and pursue opportunities, and to acquire and coordinate resources. By the same token, entrepreneurial commitment reflects the ability to see through the effort to fruition. The most important function is the commitment of competent individuals who are most likely to find a new road or a window of opportunity. In addition, the relation between entrepreneurial competence and commitment argued multiplication is not an additive: each component needs to be strong and present for the long-term viability.

The variety and amount of capital possessed and available to entrepreneurs can significantly affect both their experiences of business ownership and the performance of their firms (Davidsson \& Honig, 2003; Firkin, 2003). Based on this rationale, as shown in Figure. 1, the following hypothesis is proposed: 
H2: Entrepreneurial Capital is positively and significantly related to SMEs performance

\section{Effect of Competitive Advantage on SMEs' Performance}

Competitive advantage and firms' performance are two different constructs and their relations seems to be complex (Ma, 2000). Studies have shown that there is a significant relation between the competitive advantage and the performance (Ma, 2000; Fahy, 2000; Gimenez \& Ventura, 2002; Wang \& Lo, 2003; Wiklund \& Shepherd, 2003; Bowen \& Ostroff, 2004; Morgan et. al., 2004; Ray et. al., 2004; ). Fahy (2000) argues that the attainment of a sustainable competitive advantage position can be expected to lead to superior performance which is usually measured in conventional terms, such as market-share and profitability, that is, the financial performance measurement approach. In other words, anchoring on the view that competitive advantage and performance are two different concepts and dimensions, firms should focus their managerial strategy on attaining and sustaining competitive advantage position over their rivals. Subsequently, such a competitive advantage position will lead to superior firms' performance. Nonetheless, it should be born in mind that the existence of potentially different relations between competitive advantage and performance. Ma (2000) projected that competitive advantage does not always lead to superior performance. The notion that competitive advantage is a relational concept and it is also context-specific means that there are possibilities that competitive advantage does not result in superior firms' performance, and there are also possibilities that superior firms' performance being achieved without attaining and/or sustaining competitive advantage position. Based on this rationale, as shown in Figure. 1, the following hypothesis is proposed:

\section{H3: Competitive advantage is positively related to SMEs performance}

\section{Effects of Human and Entrepreneurial Capital on Competitive Advantage}

There are several indications that human capital is an important resource to gain competitive advantage. Habar \& Reichel (2007) studied the role of physical, human, and organizational capital in the performance of small tourism ventures, and they found that the human capital (HC) of entrepreneurs, particularly managerial skills, was the greatest contributing factor. The human capital is a source of competitive advantage since it helps to build core competencies which position the company above its competitors. HC in SMEs is different from that in LEs; the difference is due to constrains which affect smaller organizations (Hayton, 2003). HC is more important as a source of competitive advantage for SMEs than it is for LEs because HC is specific and SMEs can use it to differentiate from their competitors. Human capital has been recognized as an important resource which organizations need to develop to gain sustained competitive advantages (Bramhandkar; Erickson \& Applebee 2007). Unger et. al. (2011) also suggest that HC must be applied to specific tasks required by an organization. Boselie, Dietz, \& Boon (2005) suggest that the impact of human resources management (HRM) on internal performance indicators is what generates better financial performance. However, other empirical studies, such as Shiu (2006), Appuhami (2007), and Chan (2009), found insignificant relations between human capital development and SMEs' performance. Based on this rationale, as shown in Figure. 1, the following hypothesis is proposed:

\section{H4: Human Capital is positively related to Competitive Advantage.}

Entrepreneurial capital is also a resource and capability which present a lasting competitive advantage and superior performance to the firms. According to a resource-based theory of the firms, competitive advantage only arises from the use of scarce, intangible and firm-specific assets (Spender, 1996). Tovstiga \& Tulugurova (2009) affirmed that the firms' internal 
resource base is a determining factor of competitive advantage in SMEs. The literature further affirmed that the firms' competitive advantage and performance are largely influenced by the entrepreneurial behavior of the firms (Wiklund \& Shepherd, 2003; Zahra \& Covin, 1995). Based on this rationale, as shown in Figure. 1, the following hypothesis is proposed:

H5: Entrepreneurial Capital is positively related to Competitive Advantage.

\section{Mediation Effect of Competitive Advantage on SMEs' Performance}

Several authors suggest that the impact of HC on performance is not direct (Hayton, 2003; Jin et. al., 2010; Unger et. al., 2011). Therefore, there must be a hidden mediator between HC and performance. Many empirical studies, such as Shiu (2006), Appuhami (2007), and Chan (2009), found insignificant relations between human capital development and SMEs' performance. Most of previous literature addressing intellectual capital has ignored the significance of competitive advantage on the relations between intellectual capital and organizational performance (Chang \& Lee, 2008; Ho, 2009; Bontis, 2002; Stewart, 1997, 1998). Thus, a mediating effect of competitive advantage on the association between human and entrepreneurial capital and SMEs' performance is still a litigious matter which calls for redress in the literature. However, there is still limited empirical research which investigate the mediating effect of competitive advantage on the human and entrepreneurial capital-business performance relations. Based on this paucity, the following hypothesis is posited:

H6: Competitive advantage mediates the relation between human capital and SMEs performance.

H7: Competitive advantage mediates the relation between entrepreneurial capital and SMEs performance.

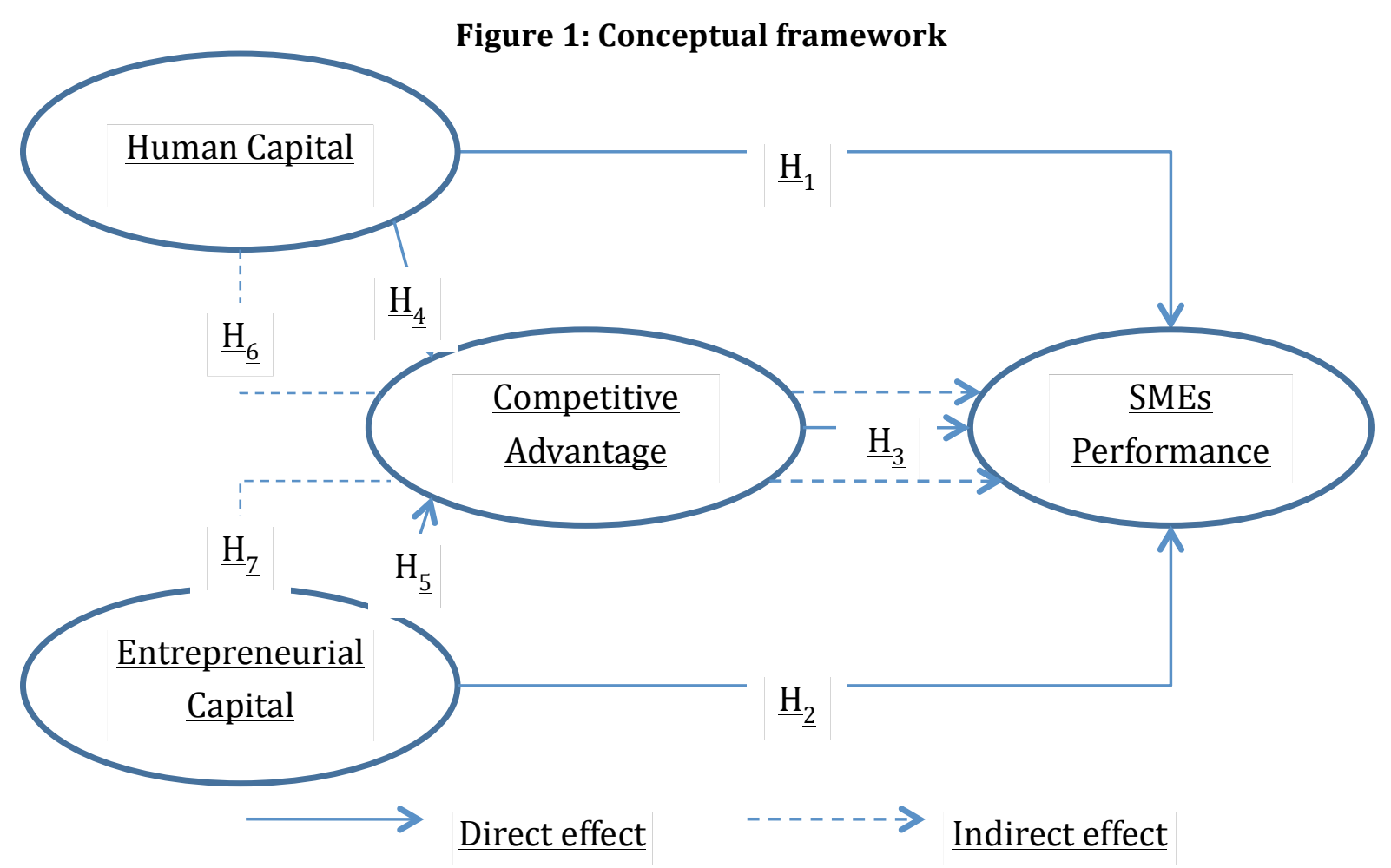

RESEARCH METHOD.

In this study, a generalized structured component analysis (GSCA) method was chosen over covariance-based methods, such as AMOS, because it supports both exploratory and 
confirmatory research (Chwelos, Benbasat, \& Dexter, 2001). GSCA is a component-based SEM method which can be used to calculate scores, and which is allowed for small samples (Hwang \& Takane, 2004; Hwang et. al., 2010). This method was chosen because of the following considerations: (1) the model in a conceptual framework consists of hierarchical causal relations; (2) GSCA is suitable for confirming the undimensionality of various latent variable indicators, both reflexive and formative; (3) GSCA is a powerful method of analysis that does not require many assumptions and can be performed on a series of latent variables simultaneously, so it is an efficient statistical tool; (4) Based on Monte Carlo simulation, SEM model with GSCA has very good performance to small size samples.

\section{Data collection.}

The present study employs a questionnaire survey approach to collect data, and all independent, mediating and dependent variables require five-point Likert-style responses ranged from 1 = "strongly disagree", through 3 = "neutral" to $5=$ "strongly agree". Variables in the questionnaire include background information, entrepreneurial capital, human capital, competitive advantage and performance. The population was the traditional herb SMEs which were located in the industrial zone of traditional herb in Sukoharjo, Central Java, Indonesia in 2015. There were two clusters of the traditional herb SMEs: 10 producers and 25 traders. The authors distributed 35 questionnaires and requested the questionnaires to be completed by top executives (owners and marketing managers) who are familiar with the topic of this study. Of the 35 questionnaires distributed, 32 responses were received. The remaining 32 valid, and the completed questionnaires were used for the quantitative analysis.

\section{Measurement.}

This study employs five main variables: perceived entrepreneurial competence, goal commitment, human capital, competitive advantage and SMEs performance. Operational definition of the research variables: (1) perceived entrepreneurial competence has been operationalized with Kolvereid's (1996) items. This construct is process-orientated and formulated towards entrepreneurship. The measure reflects perceived opportunity, capability, and control. The six items are employed. (2) Goal commitment, Boyd \& Vozikis (1994) argue that people with strong beliefs about their capabilities will be more persistent with their efforts, and they will exert greater effort to master challenges. In the present study, goal commitment is measured with two items which address commitments to professional and entrepreneurial goals. (3) Human capital in this study was measured by six items, adopted from Mahmood, et. al., (2012). (4) Competitive advantage was measured by two dimensions of differentiation innovation and market differentiation (Porter, 1985) and adopts the measurement of Kevin Zheng Zhou, 2009 with two items of differentiation innovation and four items of market differentiation. (5) SMEs performance. Subjective approach was adopted in this study where the performance of the firms was measured by the perception of the owners/managers who provide responses to the survey. They were asked to state their firms' performance on such criteria as profitability and market share. The SMEs performance measurement is referred to Mahmood, et. al., (2012), with five items.

Measurement result, construct reliability was assessed using Cronbach's alpha. In Table 1, alpha values range from 0.697 to 0.944 . In general, a Cronbach's alpha at least 0.7 is the criterion used to establish an acceptable level of reliability. However, the recommended minimum Cronbach's alpha for exploratory studies is 0.6 (Nunnally, 1978; Robinson, Shaver, \& Wrightsman, 1991). To assess convergent validity, Fornell \& Larcker (1981) proposed to examine: (1) item reliability of each construct; (2) the composite reliability (CR) of each construct; and (3) the average variance extract (AVE) of each construct. The item reliability 
was assessed through a principal component analysis as it was recommended by Straub (1989). Table 1 shows the results of the principle component analysis with varimax rotation for the constructs. Hair, Black, Babin, Anderson, and Tatham (2006) suggest the factor loadings of all individual items exceed 0.5. Fornell \& Larcker (1981) suggest that CR value should be over 0.6 and AVE value should be greater than 0.5 in each dimension. The constructs in this survey demonstrate convergent validity in Table 1. On the basis of Fornell \& Larcker's (1981) work, the discriminant validity of the constructs was tested by examining whether the square root of the AVE of each construct was greater than the highest correlation between the latent variable which involves the focal constructs (shown above the diagonal in Table 2), and the examination affirms the discriminant validity.

Table 1: Measurement model.

\begin{tabular}{|c|c|c|c|c|c|c|}
\hline \multirow{2}{*}{ VARIABLES } & & \multicolumn{3}{|l|}{ Loading } & \multirow{2}{*}{ AVE } & \multirow{2}{*}{ Alpha } \\
\hline & & Estimate & SE & CR & & \\
\hline COMMITMENT & & & & & $\begin{array}{l}0.77 \\
2\end{array}$ & 0.697 \\
\hline Commitment-1 & I am very committed to my professional goals & 0.879 & $\begin{array}{l}0.04 \\
5\end{array}$ & $19.72^{*}$ & & \\
\hline Commitment-2 & $\begin{array}{l}\text { I am very committed to my entrepreneurial } \\
\text { goals }\end{array}$ & 0.879 & $\begin{array}{ll}0.04 \\
5\end{array}$ & $19.72^{*}$ & & \\
\hline COMPETENCE & & & & & $\begin{array}{l}0.54 \\
9\end{array}$ & 0.834 \\
\hline Competence-1 & $\begin{array}{l}\text { For me, self-employment would be (very easy- } \\
\text { very difficult) }\end{array}$ & 0.729 & $\begin{array}{l}0.14 \\
1 \\
\end{array}$ & $5.16^{*}$ & & \\
\hline Competence-2 & $\begin{array}{l}\text { If I wanted to, I could easily pursue a career as } \\
\text { a self-employed person (disagree-agree). }\end{array}$ & 0.785 & $\begin{array}{l}0.16 \\
1\end{array}$ & $4.86^{*}$ & & \\
\hline Competence-3 & $\begin{array}{l}\text { As a self-employed person, how much control } \\
\text { would you have over the situation? (absolutely } \\
\text { no control-complete control). }\end{array}$ & 0.717 & $\begin{array}{l}0.33 \\
0\end{array}$ & $2.18^{*}$ & & \\
\hline Competence-4 & $\begin{array}{l}\text { The number of events outside my control } \\
\text { which could prevent me from being } \\
\text { selfemployed are (very few- numerous). }\end{array}$ & 0.732 & $\begin{array}{l}0.32 \\
8\end{array}$ & $2.23^{*}$ & & \\
\hline Competence-5 & $\begin{array}{l}\text { If I become self-employed, the chances of } \\
\text { success would be (very low-very high). }\end{array}$ & 0.770 & $\begin{array}{l}0.11 \\
2\end{array}$ & $6.91^{*}$ & & \\
\hline Competence-6 & $\begin{array}{l}\text { If I pursue a career as a self-employed person, } \\
\text { the chances of failure would be (very low-very } \\
\text { high). }\end{array}$ & 0.711 & $\begin{array}{l}0.14 \\
9\end{array}$ & $4.76^{*}$ & & \\
\hline COMPETITIVE AD & VANTAGE & & & & $\begin{array}{l}0.78 \\
6\end{array}$ & 0.944 \\
\hline Competitive -1 & $\begin{array}{l}\text { We are constantly investing in generating new } \\
\text { capabilities that give us an advantage } \\
\text { compared to our competitors. }\end{array}$ & 0.815 & $\begin{array}{l}0.05 \\
5\end{array}$ & $14.92^{*}$ & & \\
\hline Competitive -2 & $\begin{array}{l}\text { If ever there was a new way of serving } \\
\text { customers, our company would be able to offer } \\
\text { that }\end{array}$ & 0.878 & $\begin{array}{l}0.02 \\
8\end{array}$ & $31.51^{*}$ & & \\
\hline Competitive -3 & It is difficult for our competitors to imitate us & 0.941 & $\begin{array}{ll}0.02 \\
1\end{array}$ & $44.68^{*}$ & & \\
\hline Competitive -4 & $\begin{array}{l}\text { It took us several years to build our brand } \\
\text { name reputation - nobody can easily copy } \\
\text { that }\end{array}$ & 0.915 & $\begin{array}{l}0.01 \\
6\end{array}$ & $58.65^{*}$ & & \\
\hline Competitive -5 & $\begin{array}{l}\text { Our advantages are embodied in the company } \\
\text { and not in individuals - nobody can copy us } \\
\text { by stealing our employees away from us }\end{array}$ & 0.850 & $\begin{array}{l}0.03 \\
9\end{array}$ & $21.97^{*}$ & & \\
\hline Competitive -6 & $\begin{array}{l}\text { Nobody can copy our corporate routines, } \\
\text { processes and culture }\end{array}$ & 0.735 & $\begin{array}{l}0.06 \\
0\end{array}$ & $12.32^{*}$ & & \\
\hline HUMAN CAPITAL & & & & & $\begin{array}{l}0.57 \\
8\end{array}$ & 0.830 \\
\hline Human capital-1 & $\begin{array}{l}\text { My employees identify themselves with } \\
\text { company values and vision. }\end{array}$ & 0.758 & $\begin{array}{l}0.06 \\
7 \\
\end{array}$ & $11.27^{*}$ & & \\
\hline Human capital-2 & $\begin{array}{l}\text { My employees exert their best efforts to } \\
\text { achieve organizational goals and objectives. }\end{array}$ & 0.737 & $\begin{array}{l}0.07 \\
2 \\
\end{array}$ & $10.18^{*}$ & & \\
\hline Human capital-3 & $\begin{array}{l}\text { My employees are better than those of } \\
\text { competitors at innovation and R\&D. }\end{array}$ & 0.786 & $\begin{array}{ll}0.08 \\
3\end{array}$ & $9.44^{*}$ & & \\
\hline
\end{tabular}


Ngatno, Apriantni, E.P. \& Widayanto. (2016). Human Capital, Enterpreneurial Capital and SME's Performance of Traditional Herbal Industries in Central Java, Indonesia: The Mediating Effect fo Competitive Advantage. Archives of Business Research, 3(4), 9-25.

\begin{tabular}{|c|c|c|c|c|c|}
\hline Human capital-4 & $\begin{array}{l}\text { My employees are better than those of } \\
\text { competitors at reducing the company's } \\
\text { operating costs. }\end{array}$ & 0.790 & $\begin{array}{l}0.12 \\
9\end{array}$ & $6.11^{*}$ & \\
\hline Human capital-5 & $\begin{array}{l}\text { My employees are better than those of } \\
\text { competitors at responding to customer } \\
\text { demands. }\end{array}$ & 0.773 & $\begin{array}{l}0.05 \\
5\end{array}$ & $13.93^{*}$ & \\
\hline Human capital-6 & $\begin{array}{l}\text { My employees outperform those of } \\
\text { competitors. }\end{array}$ & 0.716 & $\begin{array}{l}0.09 \\
7\end{array}$ & $7.38^{*}$ & \\
\hline PERFORMANCE & & & & & $\begin{array}{ll}0.75 & 0.916 \\
0 & \end{array}$ \\
\hline Performance-1 & $\begin{array}{l}\text { The company has higher growth prospect in } \\
\text { sales than its competitors. }\end{array}$ & 0.869 & $\begin{array}{l}0.03 \\
8\end{array}$ & $22.67^{*}$ & \\
\hline Performance-2 & $\begin{array}{l}\text { The company's employees have higher job } \\
\text { satisfaction than those of competitors. }\end{array}$ & 0.854 & $\begin{array}{l}0.03 \\
4\end{array}$ & $25.45^{*}$ & \\
\hline Performance-3 & $\begin{array}{l}\text { The company's employees have higher } \\
\text { productivity than those of competitors. }\end{array}$ & 0.893 & $\begin{array}{l}0.03 \\
7\end{array}$ & $24.33^{*}$ & \\
\hline Performance-4 & $\begin{array}{l}\text { The company has better goodwill than its } \\
\text { competitors. }\end{array}$ & 0.838 & $\begin{array}{l}0.05 \\
6 \\
\end{array}$ & $15.09^{*}$ & \\
\hline Performance-5 & $\begin{array}{l}\text { The company has better quality products or } \\
\text { services than its competitors. }\end{array}$ & 0.875 & $\begin{array}{l}0.02 \\
3\end{array}$ & $38.38^{*}$ & \\
\hline
\end{tabular}

\section{Significant at 5\% (.05)}

Factor analyses were conducted to check the structure of the various scales. Due to the size of the samples, a separate analysis was conducted for the human capital, commitment, competence, competitive advantage, and performance scales. All items of latent variables are significant at 0.05 or $C R>1.96$. These results indicate that all of items indicate good convergence validity. The value of AVE (Average Variance Extracted) for all latent variables is greater than 0.50. (Hwang et. al., 2010). Correlations of latent variables are smaller than than the square root of the AVE, therefore the latent variables have adequate discriminate validity (table 2). The internal reliability of the items was verified by computing the Cronbach's alpha. Nunnally (1978) suggested that a minimum alpha of 0.6 sufficed for early stage of research. The Cronbach alpha estimated for human capital, commitment, competence, competitive advantage, and performance was more than 0.6. Therefore, the constructs were deemed to have adequate reliability.

Table 2: Correlations of Latent Variables

\begin{tabular}{|l|c|c|c|c|c|}
\hline Correlations of Latent Variables (SE) \\
\hline & Human capital & Commitment & Competence & $\begin{array}{c}\text { Competitive } \\
\text { advantage }\end{array}$ & Performance \\
\hline Human capital & 1 & $0.113(0.151)$ & $0.198(0.129)$ & $0.509(0.108)^{*}$ & $0.573(0.094)^{*}$ \\
\hline Commitment & $0.113(0.151)$ & 1 & $\begin{array}{c}0.667 \\
(0.169)^{*}\end{array}$ & $0.484(0.133)^{*}$ & $0.512(0.138)^{*}$ \\
\hline Competence & $0.198(0.129)$ & $0.667(0.169)^{*}$ & 1 & $0.569(0.118)^{*}$ & $0.601(0.142)^{*}$ \\
\hline $\begin{array}{l}\text { Competitive } \\
\text { advantage }\end{array}$ & $0.509(0.108)^{*}$ & $0.484(0.133)^{*}$ & $\begin{array}{c}0.569 \\
(0.118)^{*}\end{array}$ & 1 & $0.839(0.056)^{*}$ \\
\hline Performance & $0.573(0.094)^{*}$ & $0.512(0.138)^{*}$ & $\begin{array}{c}0.601 \\
(0.142)^{*}\end{array}$ & $0.839(0.056)^{*}$ & 1 \\
\hline
\end{tabular}

\section{Significant at .05 level}

\section{RESULTS AND DISCUSSION.}

This procedure involves the use of three multiple regression analyses: (i) the mediator (Competitive Advantage) is regressed on the independent variable (human capital and entrepreneurial capital); (ii) the dependent variable (firms' performance) is regressed on the independent variable (human capital and entrepreneurial capital; (iii) the dependent variable (firms' performance) is regressed on the independent variable (human capital, entrepreneurial capital and competitive advantage), The findings from these analyses are presented in Table 3. 


\section{DIRECT EFFECTS}

First the direct effects of human capital and entrepreneurial capital on competitive advantage were tested. The run GeSCA are shown on MODEL 1 in Table 3: (1) human capital has a significant positive effect on competitive advantage $(b=0.434 ; C R=4.35>1.96)$ - Hypothesis 4 (H4) is thus supported. The findings show that a positive human capital has a positive and significant impact on competitive advantage. This also reinforces the belief of: Habar \& Reichel, 2007; Bramhandkar, Erickson \& Applebee, 2007; Unger ET. al., 2011; Boselie, Dietz, \& Boon, 2005 about human capital being seen as a driving factor for competitive advantage. (2) Entrepreneurial capital has a positive effect on competitive advantage $(b=0.503$; $\mathrm{CR}=3.61>1.96$ ) - Hypothesis 5 (H5) is thus supported. The entrepreneurial capital shows larger coefficient than human capital in competitive advantage.

Second the direct effects of human capital and entrepreneurial capital on performance. The results in MODEL 2 and 3 show: (1) human capital has a significant positive effect on SMEs performance (see MODEL 2, $\mathrm{b}=0.505$; $\mathrm{CR}=3.75>1.96$ ). These results are in line with the opinion of previous researchers (Bosma et al. 2004; Datta et al., 2005; Oforegbunam \& Okorafor, 2010; Ojokuku \& Sajuyigbe, 2015). In the other hand, MODEL 3 shows human capital has a insignificant positive effect on SMEs performance $(b=0.232 ; C R=1.80<1.96)$. Hypothesis 1 (H1) is thus not supported. This results is in line with the opinion of Hayton, 2003; Jin et. al., 2010; and Unger ET. al., 2011. Therefore, there must be a hidden mediator between HC and performance. This also reinforces the belief of Shiu (2006), Appuhami (2007), and Chan (2009) about human capital being seen as a indirect driving factor for performance. (2) Entrepreneurial capital has a significant positive effect on SMEs' performance (in Table 2, $\mathrm{b}=$ 0.498; $C R=3.70>1.96)$. This also reinforces the belief of Davidsson \& Honig (2003) and Firkin (2003) about entrepreneurial capital being seen as a driving factor for performance. In the other hand MODEL 3 shows that entrepreneurial capital has a insignificant positive effect on SMEs' performance $(b=0.183$; $C R=1.34<1.96)$ - Hypothesis $2(\mathrm{H} 2)$ is thus not supported. This result is in line with the opinion of Chang \& Lee, 2008; Ho, 2009; Bontis, 2002; Stewart, 1997, 1998).

TABLE 3: STRUCTURAL MODEL.

\begin{tabular}{|c|c|c|c|c|}
\hline & $\begin{array}{l}\text { Mediator } \\
\text { Advantage) }\end{array}$ & (Competitive & $\begin{array}{l}\text { Dependent } \\
\text { (Performance) }\end{array}$ & Variable \\
\hline & Estimate & $\mathrm{CR}$ & Estimate & CR \\
\hline \multicolumn{5}{|l|}{ MODEL 1} \\
\hline Human Capital & 0.434 & $4.35^{*}$ & & \\
\hline Entrepreneurial Capital (Commitment*Competence) & 0.503 & $3.61^{*}$ & & \\
\hline FIT & 0.606 & & & \\
\hline AFIT & 0.578 & & & \\
\hline GFI & 0.993 & & & \\
\hline \multicolumn{5}{|l|}{ MODEL 2} \\
\hline Human Capital & & & 0.505 & $3.75^{*}$ \\
\hline Entrepreneurial Capital (Commitment*Competence) & & & 0.498 & $3.70^{*}$ \\
\hline FIT & & & 0.587 & \\
\hline AFIT & & & 0.557 & \\
\hline GFI & & & 0.992 & \\
\hline \multicolumn{5}{|l|}{ MODEL 3} \\
\hline Human Capital & & & 0.232 & 1.80 \\
\hline Entrepreneurial Capital (Commitment*Competence) & & & 0.183 & 1.34 \\
\hline Competitive Advantage & & & 0.626 & $4.75^{*}$ \\
\hline FIT & & & 0.623 & \\
\hline AFIT & & & 0.595 & \\
\hline GFI & & & 0.977 & \\
\hline
\end{tabular}

$\mathrm{CR}^{*}=$ significant at .05 level 


\section{Indirect Effects of Competitive Advantage}

The three-step regression procedure which Baron \& Kenny (1986) recommended in examining the mediating effect of competitive advantage was followed. As it is shown previously, the human capital and the entrepreneurial capital have positive and significant effects on competitive advantage. In addition, the human capital and the entrepreneurial capital have positive and significant effects on the SMEs performance. When the competitive advantage is included in MODEL 3 (Table 3), it reveals a positive and significant effect on the SMEs' performance, in support of $\mathrm{H} 3(\mathrm{~b}=0.626$; $\mathrm{CR}=4.75>1.96)$. The inclusion of competitive advantage leads to a hard decrease in the effect human capital and entrepreneurial capital (from 0.505 to 0.232 and from 0.498 to 0.183 ) and insignificant ( $C R=1.80<1,96$ and $\mathrm{CR}=1.34<1.96)$, suggesting complete mediation. It means that the human capital and the entrepreneurial capital influence the SMEs performance through competitive advantage. Model comparisons based on the FIT and AFIT difference test indicate that MODEL 3 performs better than both MODEL 1 and MODEL 2. Therefore, overall, the model fit is superior when competitive advantage is included. Hypothesis 6 (H6) and 7 (H7) are thus supported. This result is in line with the opinion of several authors that the impact of HC on performance is not direct (Hayton, 2003; Jin et. al., 2010; Unger et. al., 2011). Many empirical studies, such as Shiu (2006), Appuhami (2007), and Chan (2009), found insignificant relations between human capital development and SMEs' performance. Beside that, most of previous literature addressing intellectual capital has ignored the significance of competitive advantage on the relations between intellectual capital and organizational performance (Chang \& Lee, 2008; Ho, 2009; Bontis, 2002; Stewart, 1997, 1998).

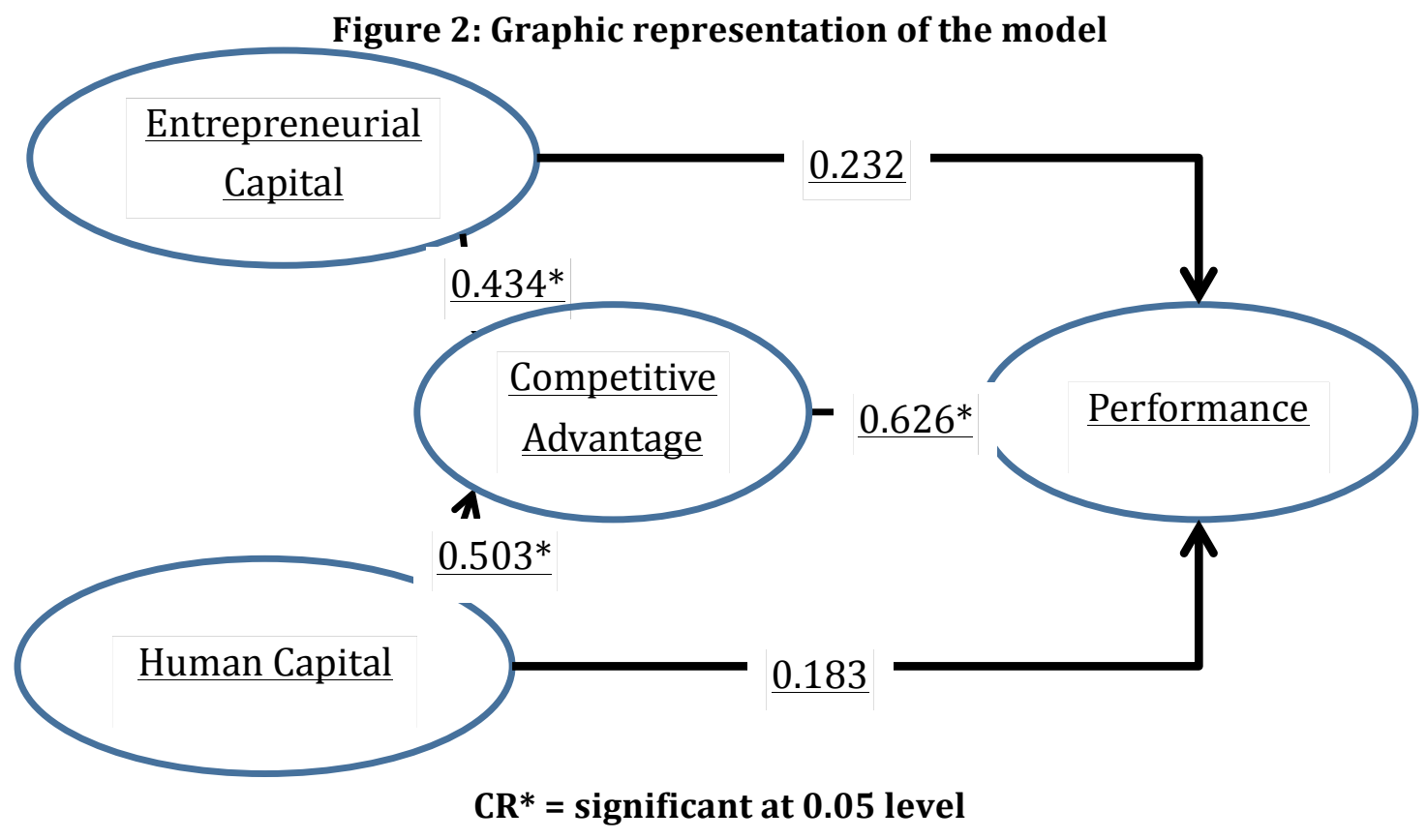

\section{Theoretical contributions}

This study contributes to SMEs performance in two main ways. First, the study shows that competitive advantage plays an important role in the SMEs performance by fully mediating the effects of the human capital and the entrepreneurial capital on the SMEs performance. In other words, the human capital and the entrepreneurial capital are intrinsically valuable; their value on SMEs performance is realized through competitive advantage. This is an important finding as it indicates that competitive advantage is an important mediator in the relation between the human capital and the entrepreneurial capital and the SMEs' performance. Second, the human capital and the entrepreneurial capital have the same effects on SMEs' performance. The full 
mediating role of competitive advantage on the SMEs' performance indicates that the human capital and the entrepreneurial capital are completely through competitive advantage.

\section{Managerial implications}

This study calls on managers to consider the human capital and the entrepreneurial capital which they use in the SMEs' performance and in properly designing competitive advantage. The human capital and the entrepreneurial capital appear to influence the design of competitive advantage, which in turn affect the SMEs' performance. Thus, the new insight for managers is that the human capital and the entrepreneurial capital are inherently valuable for the SMEs' performance, but emphasizing the competitive advantage may be detrimental to the SMEs' performance. In this respect, the measures of the human capital and the entrepreneurial capital could serve as guides for managers who want to collect and use utilitarian and hedonic benefits in line with these attributes. From a practitioner's perspective, the objective of this study has been to provide practical insights into ways of enhancing the SMEs' performance in the traditional herbal industries.

This study also provides new insights into the relative importance of the human capital and the entrepreneurial capital in enhancing competitive advantage and performance. Specifically, the entrepreneurial capital is more important than the human capital in determining competitive advantage (as shown in MODEL 1). In contrast, when the direct effects of the human capital and the entrepreneurial capital on performance (see MODEL 2) is to be considered, the human capital appear to be more salient than the entrepreneurial capital.

\section{Limitations and future research directions}

This study has several limitations that should be considered in the interpretations of the findings. First, only small tradtional herbal industries were investigated. The small industries which are more specific in nature, such as the batik, toys, and craft SMEs, may result in different relations between the constructs of the models. Second, the data was collected in a single central area of traditional herbal industry. There was no evidence of sampling bias, but future studies would benefit from inclusion of a wider geography scope. The findings of this study also underscore the need for researchers to examine other factors which may also be antecedents of the SMEs' performance and competitive advantage.

\section{References}

ACS ZJ \& Preston L (1997). Small and Medium-Sized Enterprises, Technology, and Globalization: Introduction to a Special Issue on Small and Medium-Sized Enterprises in the Global Economy. Small Business Economics, 9: 1-6.

Appuhami R (2007). The impact of intellectual capital on investors' capital gains on shares: An empirical investigation of Thai banking, finance and insurance sector. Inter Man Review, 3(2): 14-25.

Becker, G. (1964), Human Capital, Chicago: The University of Chicago Press.

Becker, G. S. (1993). Human Capital: A Theoretical and Empirical Analysis with Special Reference to Education (3rd Ed.). Chicago: University of Chicago Press.

Blaug, Mark. (1976). Kuhn versus Lakatos, or paradigm versus research programmes in the history of economics. In Method and appraisal in economics, ed. S. J. Latsis. Cambridge: Cambridge University Press, 149-180.

Bontis, N. \& Fitz-enz, J. (2002). Intellect ual capital ROI: a causal map of human capital antecedents and consequents, Journal of Intellectual Capital, Vol. 3, No. 3, pp.223-247.

Boselie, P., Dietz, G., \& Boon, C. (2005). Commonalities and contradictions in HRM and performance research. Human Resource Management Journal, 15, 67-94.

Bosma, N., M. van Prag., R. Thurik, \& G. De Wit (2004). The Value of Human and Social Capital Investments for the Business Performa nce of Startups. Small Business Economics 23(3), 227-236 
Ngatno, Apriantni, E.P. \& Widayanto. (2016). Human Capital, Enterpreneurial Capital and SME's Performance of Traditional Herbal Industries in Central Java, Indonesia: The Mediating Effect fo Competitive Advantage. Archives of Business Research, 3(4), 9-25.

Bourdieu, P. (1983). The forms of capital. In J. Richardson (Ed.), Handbook of theory and research for the sociology of education (pp.241-258). New York: Greenwood Press.

Bowen, D. E. \& Ostroff, C. (2004). Understanding HRM-firm performance linkages: The role of "strength" of the HRM system. Academy of Management Review, 29, 203-221

Boyd, N. G., \& Vozikis, G. S. (1994). The influence of self-efficacy on the development of entrepreneurial intentions and actions. Entrepreneurship Theory and Practice, 18, 64-77.

Bramhandkar, A., Erickson, S., \& Applebee, I. (2007). Intellectual Capital and Organizational Performance an Empirical Study of the Pharmaceutical Industry, ECKM 2007, 8th European Conference on Knowledge Management, Barcelona.

Brush, C.G. \& Vanderwerf, P.A. (1992). A comparison of methods and sources for obtaining estimates of new venture performance. Journal of Business Venturing, 7(2), 157-170.

Bygrave, W. D. (1989). The entrepreneurship paradigm (i): A philosophical look at its research methodologies. Entrepreneurship Theory and Practice, Fall 1989

Chan K.H. (2009). Impact of intellectual capital on organisational performance. An empirical study of companies in the Hang Seng Index (Part 1). The Learning Organisation, 16(1): 4-21.

Chandler, G. \& Hanks, S. H. (1994). Market attractiveness, resource-based capabilities, venture strategies and venture performance. Journal of business venturing, 9(4), 331-349.

Chang, S.C. \& Lee, M.S. (2008), “The linkage between knowledge accumulation capability and organizational innovation", Journal of Knowledge Management, Vol. 12 No. 1, pp. 3-20.

Chwelos, P., Benbasat, I., \& Dexter, A. S. (2001). Empirical test of an EDI adoption model. Information Systems Research, 12 (3), 304-321.

Cooper, Arnold C. (1993), Challanges in Predicting New Firm Performance, Journal of Business Venturing, 8 (2), pp. 241-253.

Datta, D. K., Guthrie, J. P., \& Wright, P. M. (2005). Human resource management and labor productivity: Does industry matter? Academy of Management Journal, 48, 135-145.

Davidsson, P. \& Honig, B. (2003) 'the Role of Social and Human Capital among Nascent Entrepreneurs', Journal of Business Venturing, 18(3), $301-31$

Dollinger, (2008), Entrepreneurship: Strategies and Resources, Illionois: Irwin. Fourth edition. Entrepreneurship: New Perspectives in a Global Age. Aldershot: Ashgate, 57-75.

Erikson Truls, (2002). Entrepreneurial capital: the emerging venture's most im-portant asset and competitive advantage, Journal of Business Venturing 17 (2002) 275 - 290

Fahy, J. (2000). The resource-based view of the firm: some stumbling-blocks on the road to understanding sustainable competitive advantage. Journal of European Industrial Training, 24/2/3/4 [2000] 94-104.

Fatoki (2011), the Impact of Human, Social and Financial Capital on the Performance of Small and Medium-Sized Enterprises (SMEs) in South Africa, Journal of Social Science, 29(3): 193-204

Firkin, P. (2003). Entrepreneurial Capital. In De Bruin, A. \& Dupuis, A. (Eds.).

Fornell, C., \& Larcker, D.F., 1981. Evaluating structural equation models with unobservable variables and measurement error. Journal of Marketing Research 18 (1), 39-50.

Gartner, W. B. \& Carter, N. M. (2003). Entrepreneurial Behavior and Firm Organizing Processes. In Handbook of Entrepreneurship Research, Z. J. Acs \& D. B. Audretsch (Eds), pp. 195-221. Kluwer Academic Publishers, Boston, MA.

Gimenez, C., \& Ventura, A. (2002). Supply chain management as a competitive advantage in the Spanish grocery sector. Published Working Paper. No. 2, 04/2002, Barcelona, Spain: Universitat Pompeu Fabra' (UPF).

Glade, W., (1967). Approaches to a Study of Entrepreneurial Formation", Explorations in Entrepreneurial History, Vol. 4, No. 3, pp. 245-259. 
Granovetter, M.S (1983), The Strength of Weak Ties: A Network Theory Revisited." Sociological Theory 1 (1983): 201-33.

Habar, S. \& Reichel, A. (2007). The cumulative nature of the entrepreneurial process: The contribution of human capital, planning and environmental resources to small venture performance. Journal of Business Venturing, 22(1), 119-145.

Haber S., \& A. Reichel (2007), “The cumulative nature of the entrepreneurial process: The contribution of human capital, planning and environment resources to small venture performance”, Journal of Business Venturing, 22(1), 119-145.

Hair, J., Black, B. Babin, B., Anderson, R. \& Tatham, R. (2006). Multivariate Data Analysis (6th edition). Upper Saddle River, NJ: Prentice-Hall.

Hayton, J. C. (2003). Strategic human capital management in SMEs: An empirical study of entrepreneurial performance. Human Resource Management, 42(4), 375-391.

Ho, C.T. (2009). “The relationship between knowledge management enablers and performance”, Industrial Management \& Data Systems, Vol. 109 No. 1, pp. 98-117.

Hofer, C. W., \& Schendel, D. Strategy formulation: Analytical concepts. St. Paul, MN: West, 1978.

Hwang, H., \& Takane, Y. (2004). Generalized structured component analysis. Psychometrika, 69 (1), pp. 81-99.

Hwang, H., Malhotra, N. K., Kim, Y., Tomiuk, \& Hong (2010). A comparative study on parameter recovery of three approaches to structural equation modeling. Journal of Marketing Research, 47, pp. 699-712

Isaksen, E.J., (2006). Early Business Performance: Initial factors effecting new business outcomes, PhD Series, No.6, Bodo Graduate School of Business, Norway

Janine Nahapiet \& Sumantra Ghoshal (1998) Social Capital, Intellectual Capital, and the Organizational Advantage, The Academy of Management Review, Vol. 23, No. 2. (Apr., 1998), pp. 242-266.

Jin, Y., Hopkins, M. M., \& Wittmer, J. L. S. (2010). Linking Human Capital to Competitive Advantages: Flexibility in a Manufacturing Firm's Supply Chain. Human Resource Management, 49(5), 939 - 963.

Johannisson, B. (1988) Business Formation - a network approach Scandinavian Journal of Management, Vol. 4, pp. 83-99.

Kevin Zheng Zhou, James R. Brown, \& Chekitan S. Dev (2009). Market orientation, competitive advantage, and performance: A demand-based perspective, Journal of Business Research 62 (2009) 1063 - 1070

Koch, M.J., \& McGrath, R.G. 1996. Improving Labour Productivity: Human Resource Management Policies Do Matter. Strategic Management Journal, 17: 335-54.

Kolvereid, L. (1996). Prediction of employment status choice intentions. Entrepreneurship Theory and Practice, 21(1), 47-57.

Kusar J, Duhovnik J, Grum J, \& Starbek M (2004). How to reduce new product development time. Robotics and Computer-Integrated Manufacturing, 20: 1-15.

Leibenstein \& Harvey (1968). "Entrepreneurship and Development," American Economic Review 58, 2, pp.72-83.

Lo, Andrew W., \& Jiang Wang, 2003, Trading Volume, in M. Dewatripont, L. Hansen, \& S. Turnovsky, eds.: Advances in Economics and Econometrics: Theory and Applications, Eighth World Congress, Volume II (Cambridge University Press).

Lussier, R. N., \& Pfeifer, S. (2001). A crossnational prediction model for business success. Journal of Small Business Management, 39 (3), 228-239.

Ma, (2000). Competitive advantage and firm performance. Competitiveness Review, 10(2), 16.

Mahmood I, Habib Ahmad, \& Ch. Mazhar Hussain (2012). Impact of Organizational Human Capital on Organizational Performance, Asian Journal of Business and Management Sciences, Vol. 1 No. 4, pp 22-28.

Markman, G.D. \& Baron, R.A. (2003), “Person-entrepreneurship fit: why some people are more.

Morgan, N. A., Kaleka, A., \& Katsikeas, C. S. (2004). Antecedents of export venture performance: A theoretical model and empirical assessment. Journal of Marketing, 68, 90-108. 
Ngatno, Apriantni, E.P. \& Widayanto. (2016). Human Capital, Enterpreneurial Capital and SME's Performance of Traditional Herbal Industries in Central Java, Indonesia: The Mediating Effect fo Competitive Advantage. Archives of Business Research, 3(4), 9-25.

Morris, M.H. (1998). Entrepreneurial Intensity: Sustainable Advantages for Individuals Organizations and Societies. Greenwood Publishing, Westport.

Nixon Kamukama, Augustine Ahiauzu \& Joseph M. Ntayi, (2011). Competitive advantage: mediator of intellectual capital and performance, Journal of Intellectual Capital, 12 isue 1 pp 152 - 164

Nunnally, J. C. (1978). Psychometric theory (2nd Ed.).(New York: McGraw-Hill)

Nunnally, J. C., \& Bernstein, I. H. (1994) Psychometric theory (3rd Ed.). New York, NY: McGraw-Hill, Inc.

Oforegbunam, E. T., \& Okorafor, G. T. (2010). Effects of Human Capital Development on the performance of Small \& Medium Scaled Enterprises in the Southeastern Region of Nigeria. Journal of Sustainable Development in Africa, 12(8), 49-58

Ojokuku, R.M. \& Sajuyigbe, A.S, (2015) Effect of Human Capital Development on the Performance of Small and Medium Scale Enterprises in Nigeria, Journal of Emerging Trends in Economics and Management Sciences (JETEMS) 6(1):88-93 (C) Scholarlink Research Institute Journals, 2015 (ISSN: 2141-7024)

Onugu, B. A. N. (2005): "Small and Medium Enterprises (SMEs) in Nigeria: Problems and Prospects". St. Clements University Dissertations and Theses, in (http://stclements.edu/ grad/gradonug.pdf). Accessed 12/09/2012.

Pont, M. \& Shaw, R. (2003). Measuring marketing performance: A critique of empirical literature. Journal Business Research, 13(2), 153-172.

Porter, M.E. (1985), Competitive Advantage, Creating and Sustaining Superior Performance, the First Free Press, New York.

Rauch, A., \& Frese, M. (2000). Psychological approaches to entrepreneurial success: A general model and an overview of findings. In C.L. Cooper \& I.T. Robertson (Eds.), International review of industrial and organizational psychology (Vol. 15, pp. 101-141). Chichester, UK: Wiley.

Ray, G., Barney, J. B., \& Muhanna, W. A. (2004). Capabilities, business processes, and competitive advantage: Choosing the dependent variable in empirical tests of the resource-based view. Strategic Management Journal, 25, 23-37.

Robinson, J. P., Shaver, P. R., \& Wrightsman, L. S. (Eds.). (1991). Measures of personality a social psychological attitudes. San Diego: Academic Press.

Schultz, T.W., (1970). The 'reckoning of education as human capital'. In: Hansen, W.L. (Ed.), Education, Income, and Human Capital. NBER Studies in Income and Wealth, vol. 35. Columbia University Press, New York, pp. 297306.

Shanahan, S. E., \& N. B. Tuma (1994), "The Sociology of Distribution and Redistribution”,in N. J. Smelser \& R. Swedberg (eds), The Handbook of Economic Sociology, pp.733-765, Princeton, NJ, Princeton University Press.

Shaver, K.G., \& Scott, L.R. (1991) Person, process, choice: The psychology of new venture creation.

Entrepreneurship Theory and Practice, pp. 23-45.

Shiu H.J. (2006). The application of the value added intellectual coefficient to measure corporate performance: Evidence from technological firms. International J of Management, 23(2): 356-365.

Spender, J. C. (1996). Making knowledge the basis of a dynamic theory of the firm, Strategic Management Journal (17), winter, pp. 45-62.

Stevenson, H.H. \& Jarillo, J.C. (1990). A paradigm of entrepreneurship research: Entrepreneurial management. Strategic Management Journal, 11, 17-27.

Stewart, T. (1997). Intellectual capital. New York: Doubleday.

Straub, D. W. (1989). “Validating Instruments in MIS Research,” MIS Quarterly (13:2), pp. 147-169.

Tomer, John F. (1987). Organizational Capital: The Path to Higher Productivity and Well-being. New York: Praeger.

Tovstiga G \& Tulugurova E (2009). Intellectual capital practices: a fourregion comparative study. J. Intellect. Capital, 10 (1):70-80.

Ulrich D (1998). Delivering results a new mandate for human resources Professional. Harvard Business Review. 
Unger, J. M., Rauch, A., Frese, M., \& Rosenbusch, N. (2011). Human capital and entrepreneurial success: A metaanalytical review. Journal of Business Venturing, 26(3), 341-358.

Venkatraman, N. \& Ramanujam, V. (1986), Measurement of business performance in strategy research: A comparison of approaches, Academy of Management Review, 1(4), pp.801-808.

Wengel, J., \& E. Rodriguez (2006), "SME export performance in Indonesia after the crisis”, Small Business Economics, 26: 25-37.

Wiklund, Johan \& Dean Shepherd (2003), Knowledge-Based Resources, Entrepreneurial Orientation, and the Performance of Small and Medium-Sized Businesses, Strategic Management Journal, 24, 1307-1314.

Yau, O. H. M., Chow, R. P. M., Sin, L. Y. M., Tse, A. C. B., Luk, C. L., \& Lee, J. S. Y. (2007). Developing a scale for stakeholder orientation. European Journal of Marketing, 41(11/12): 1306.

Yu-Ching, C., Kuo-Pin, Y., \& Yu, C.-M. J. (2006). Performance, Internationalization, and Firm-Specific Advantages of SMEs in a Newly-Industrialized Economy. Small Business Economics, 26(5), 475-492.

Zahra, S. A., \& Covin, J. G. (1995). Contextual influences on the corporate entrepreneurship performance relationship: A longitudinal analysis. Journal of Business Venturing, 10(3), 43-58. 